\title{
A review of the pressure-temperature-time evolution of the Limpopo Belt: Constraints for a tectonic model
}

\author{
M. Rigby ${ }^{\mathrm{a}}$, H. Mouri ${ }^{\mathrm{a}}$ and G. Brandl ${ }^{\mathrm{b}}$ \\ ${ }^{a}$ Department of Geology, University of Pretoria, South Africa \\ ${ }^{\mathrm{b}}$ Council for Geoscience, Limpopo Unit, Polokwane, South Africa
}

\section{Abstract}

Published literature argues that the Limpopo Belt can be subdivided into three zones, each with a distinctive geological character and tectono-metamorphic fingerprint. There are currently two contrasting schools of thought regarding the tectono-metamorphic evolution of the CZ. One camp argues that geochronological, structural and prograde pressure-temperature $(P-T)$ evidence collectively indicate that the $\mathrm{CZ}$ underwent tectono-metamorphism at ca. $2.0 \mathrm{Ga}$ which followed a clockwise $P-T$ evolution during a transpressive orogeny that was initiated by the collision of the Kaapvaal and Zimbabwe cratons. Deformation and metamorphism consistent with this scenario are observed in the southern part of the NMZ but are curiously absent from the whole of the SMZ. The opposing view argues that the peak metamorphism associated with the collision of the Kaapvaal and Zimbabwe cratons occurred at ca. 2.6 Ga and the later metamorphic event is an overprint associated with reactivation along Archean shear zones. Post-peakmetamorphic conditions, which at present cannot be convincingly related to either a ca. 2.6 or $2.0 \mathrm{Ga}$ event in the $\mathrm{CZ}$ reveal contrasting retrograde paths implying either nearisothermal decompression and isobaric cooling associated with a 'pop-up' style of exhumation or steady decompression-cooling linked to exhumation controlled by erosion. Recent data argue that the prograde evolution of the ca. 2.0 Ga event is characterised by isobaric heating prior to decompression-cooling. Contrasting $P-T$ paths indicate that either different units exist within the $\mathrm{CZ}$ that underwent different $P-T$ evolutions or that some $P-T$ work is erroneous due to the application of equilibrium thermobarometry to mineral assemblages that are not in equilibrium. The morphology of the $P-T$ path(s) for the ca. 2.6-2.52 Ga event are also a matter of dispute. Some workers have postulated an anticlockwise $P-T$ evolution during this period whilst others regard this metamorphic event as following a clockwise evolution. Granitoid magmatism is broadly contemporaneous in all three zones at ca. 2.7-2.5 suggesting a possible causal geodynamic link. $P-T$ contrasts between and within the respective zones prevent, at present, the construction of a coherent and inter-related tectonic model that can account for all of the available evidence. Detailed and fully-integrated petrological and geochronological studies are required to produce reliable $P-T-t$ paths that may resolve some of these pertinent issues. 


\section{Article Outline}

1. Introduction

2. Geological context

2.1. The Central Zone

2.2. The Southern Marginal Zone

2.3. The Northern Marginal Zone

3. $P-T-t$ evolution

3.1. The Central Zone

3.2. The Southern Marginal Zone

3.3. The Northern Marginal Zone

4. Discussion: implications for tectonic models

5. Summary and conclusions

Acknowledgements

References

\section{Introduction}

The Limpopo Belt of southern Africa (Fig. 1) is an extensive high-grade terrane (HGT) that can be subdivided into three lithologically and structurally distinct zones which collectively encompass $c .150,000 \mathrm{~km}^{2}$ of southern Zimbabwe, eastern Botswana and northern South Africa (e.g. [Brandl, 1983] and [Van Reenen et al., 2004]). The Northern Marginal Zone (NMZ) is separated from the Zimbabwe Craton (ZC) by a southward dipping ductile shear zone known as the North Limpopo Thrust Zone (NLTZ) (e.g. Blenkinsop and Mkweli, 1992). Similarly, the Southern Marginal Zone (SMZ) is separated from the Kapvaal Craton (KC) by the northwards dipping Hout River Shear Zone (HRSZ) (e.g. [Van Reenen et al., 1990] and [Smit et al., 1992]). The NMZ and SMZ are commonly regarded as granulite-facies equivalents of the Archean granitegreenstone successions which prevail in the adjacent cratons (e.g. [Du Toit et al., 1983] and [Van Reenen et al., 1992]). Conversely, the Central Zone (CZ) forms a lithological diverse and distinct supracrustal sequence (e.g. [Brandl, 1983], [Van Reenen et al., 1992] and [Holzer et al., 1998]) that is separated from the NMZ and SMZ by two major ENEWSW trending, inward-dipping, strike-slip shear zones, the Palala-Sunnyside (PSZ) and Magagohate-Triangle (MSZ) (e.g. [Van Reenen et al., 1992], [Kamber et al., 1995a] and [Kamber et al., 1995b]). 


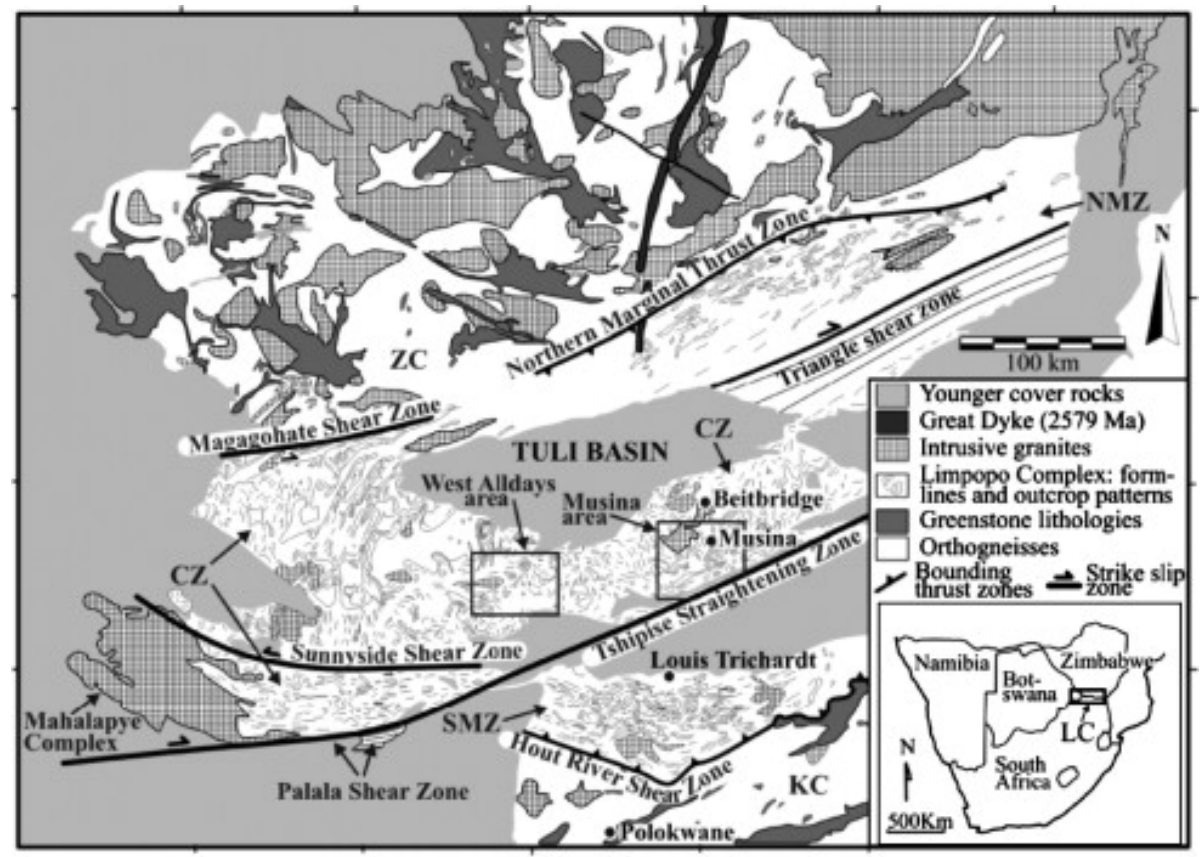

Fig. 1. A geological map of the Limpopo belt and adjacent cratons (after Boshoff et al., 2006).

The metamorphic and associated magmatic and deformational characteristics of all three zones have traditionally been attributed to the 'Limpopo Orogeny' - an AlpineHimalayan style continental collision event occurring between the Zimbabwe and Kapvaal cratons at ca. 2.7-2.6 Ga (e.g. [Roering et al., 1992], [Van Reenen et al., 1992] and [Treloar et al., 1992]). The relative timing, style and extent of the magmatic and metamorphic activity have, over the years, come into question by numerous workers (e.g. [Harris and Holland, 1984], [Droop, 1989], [Stevens and Van Reenen, 1992a], [Hisada and Miyano, 1996], [Jaeckel et al., 1997], [Holzer et al., 1998], [Kroner et al., 1998], [Kroner et al., 1999], [Smit et al., 2001], [Van Reenen et al., 2004], [Zeh et al., 2004], [Zeh et al., 2005], [Hisada et al., 2005] and [Boshoff et al., 2006]) who have defined different pressure-temperature-time $(P-T-t)$ paths for each of the zones. This has ultimately led to a great deal of controversy surrounding the tectonic evolution of the Limpopo Belt. In this paper we attempt to review the current understanding of the $P-T-t$ evolution of the Limpopo Belt, highlighting the significance of inter-related geochronological and petrological studies in unravelling the complex tectonic history of this ancient mountain belt.

\section{Geological context}

\subsection{The Central Zone}

The $\mathrm{CZ}$ is characterised by a wide range of lithologies including a supracrustal succession termed the Beit Bridge complex (BBC) and several suites of tonalitictrondjemitic and granodioritic (TTG) orthogneiss, including the Sand River Gneiss 
(SRG) and the Alldays Gneiss (AG) (e.g. [Van Reenen et al., 1992] and [Kroner et al., 1999]). The BBC is composed of predominantly leucocratic quartzo-feldpathic gneiss, quartzite and marble with intercalated metapelitic gneiss, magnetite quartzite and mafic granulites (e.g. [Coward, 1983], [Watkeys et al., 1983] and [Van Reenen et al., 1990]). The well-developed metamorphic and deformational characteristics of the BBC obscure the sedimentological and stratigraphic relationships between these lithologies (e.g. Brandl, 1983). The metapelites are mineralogically diverse and include a variety of assemblages e.g. Garnet + Cordierite + Spinel + Biotite + Sillimanite + K-feldspar and Gedrite + Sapphirine + Cordierite. Many of these mineral assemblages preserve complex reaction textures including symplectitic intergrowths (e.g. Droop, 1989). The metapelitic gneisses are commonly migmatitic, forming predominantly layered and stromatic textures (e.g. [Chavagnac et al., 2001] and [Hisada et al., 2005]). There is some dispute as to whether the BBC forms a supracrustal unit that was deposited on top of the SRG, and its compositional variants (e.g. Barton et al., 1983) or whether the SRG's igneous protoliths were emplaced into the BBC ([Hofmann et al., 1998] and [Kroner et al., 1998]). The latter observation is supported by dating of detrital zircons from a metapelite of the BBC using SHRIMP to determine U-Pb ages between 3.36 and 3.7 Ga (Kroner et al., 1998) and $\mathrm{U}-\mathrm{Pb}$ and $\mathrm{Pb}-\mathrm{Pb}$ dates of $\mathrm{ca}$. 3.2 Ga for the emplacement of the SRG's igneous protoliths ([Jaeckel et al., 1997] and [Kroner et al., 1999]). The detrital zircon data thus constrains the maximum age of deposition but does not necessarily imply that the metapelites are older than $3.2 \mathrm{Ga}$.

On the basis of comprehensive zircon dating Kroner et al. (1999) concluded that the orthogneisses of the $\mathrm{CZ}$ could be subdivided into three main age groups. The oldest group (3188-3314 Ma) consists of predominantly TTG orthogneiss, termed the Sand River granitoid Suite (which includes the SRG), is found in relatively small domains across the whole of the $\mathrm{CZ}$ and are interpreted to reflect the remnants of a once more widespread early-Archean terrane (Kroner et al., 1999). A prevalent early-Archean magmatic event is further supported by the emplacement of the layered metagabbroic Messina Suite at ca. 3.0 Ga (Barton, 1996). The most abundant orthogneisses, designated to include the Alldays, Singelele, Zanzibar, Bulai and Zoetfontein Gneisses, belong to the 2734-2604 Ma age group that were emplaced into the already ductile and deformed gneisses of the oldest group ([Jaeckel et al., 1997] and [Kroner et al., 1999]). The youngest age group is based solely on one sample - the Tshipise Gneiss, a strongly deformed orthogneiss with a protolith emplacement age of ca. $2510 \mathrm{Ma}$ which has been interpreted to suggest that part of the ductile deformation history of the CZ occurred in the early Proterozoic (Kroner et al., 1999). The second period of granitoid magmatism is broadly contemporaneous with the emplacement of the Bulai Pluton which is clearly intrusive into migmatitic paragneiss of the BBC (Watkeys et al., 1983) and can be subdivided into an enderbitic intrusive phase at ca. 2.6 Ga and a granitic phase at $2.57 \mathrm{Ga}$ (Barton et al., 1994). Finally a ca. $2.0 \mathrm{Ga}$ metamorphic event was proposed (e.g. Jaeckel et al., 1997 and references herein) on the basis of dating rare metamorphic zircon grains and more widespread metamorphic overgrowths. More recently, a ca. $2.0 \mathrm{Ga}$ metamorphic was further supported by the single zircon ion probe dating studies of (Buick et al., 2006) and (Mouri et al., this volume). 


\subsection{The Southern Marginal Zone}

Rocks of the SMZ represent high-grade metamorphic equivalents of the adjacent granitegreenstone terranes that comprise the KC (e.g. [Du Toit et al., 1983] and [Van Reenen et al., 1988]). Isotope and geochemical comparisons of the rocks from the SMZ and KC provide evidence to suggest that these rocks were derived from a common crustal source, which was formed between 3.05 and $2.9 \mathrm{Ga}$ (Kreissig et al., 2000). The granulite facies rocks of the SMZ were thrust onto the adjacent $\mathrm{KC}$ along the mylonitic oblique-dip slip HRSZ (e.g. Smit et al., 1992). The timing of this major thrust is constrained by zircon dates from the syn-kinematic Matok Intrusive Complex (MIC) to be between ca. 2671 and $2664 \mathrm{Ma}$ ([Barton and Van Reenen, 1992] and [Barton et al., 1992]). The MIC comprises three compositionally distinct phases: (1) a charno-enderbitic phase determined by Bohlender et al. (1992) to be the product of dry crustal melting which was emplaced along the granulite facies Matok Shear Zone (MSZ) (part of the HRSZ) at ca. $2671 \mathrm{Ma}$ (Barton et al., 1992); (2) a ganodioritic phase containing xenoliths of the older charno-enderbititic phase, and (3) a leucogranitic phase which marks the end of the MIC magmatic evolution (Barton et al., 1983). On the basis of $\mathrm{U}-\mathrm{Pb}$ dating of zircons Barton et al. (1992) determined emplacement ages between 2667 and $2664 \mathrm{Ma}$ for the granodioritic and granitic phases of the MIC.

Petrological studies have demonstrated (e.g. Van Reenen et al., 1990) that the SMZ can be subdivided into a northern high-grade granulite zone and a southern rehydrated granulite zone separated by a retrograde ortho-amphibole isograd. The high-grade granulite zone is dominated by the volumetrically abundant Opx-bearing, tonalitic to trondhjemitic gneiss known as the Baviaanskloof gneiss (e.g. Van Reenen, 1983). Metapelitic gneiss is the most common former supracrustal lithology and along with subordinate mafic and ultramafic units these granulites now comprise the Banderlierkop Formation (e.g. [Du Toit et al., 1983] and [Van Reenen et al., 1992]). The metapelitic granulites are commonly migmatitic and preserve a typical assemblage of

Garnet + Orthopyroxene + Biotite + Plagioclase + Quartz \pm Cordierite \pm Spinel \pm Sillima nite \pm Kyanite (Stevens and Van Reenen, 1992a). The rehydrated granulites are characterised by the assemblage

Garnet + Biotite + Gedrite + Anthophyllite \pm Cordierite \pm Orthopyroxene \pm Kyanite. The ortho-amphibole isograd is clearly defined by the replacement of orthopyroxene by anthophyllite, commonly preserving little or no evidence of a previous high-grade history ([Van Reenen et al., 1992] and [Stevens and Van Reenen, 1992a]).

\subsection{The Northern Marginal Zone}

The NMZ represents reworked granite-greenstone lithologies of the adjacent craton (ZC) (e.g. [Robertson and Du Toit, 1981] and [Fripp, 1983]). Geochemical fractionations ([Rollinson, 1993], [Luais and Hawkesworth, 1994] and [Berger et al., 1995]), Nd model ages ([Taylor et al., 1991] and [Berger et al., 1995]) and $\mathrm{Pb}$ isotope systematics ([Taylor et al., 1991] and [Berger and Rollinson, 1997]) strongly support this assertion. In contrast to the SMZ it consists of predominantly charno-enderbites and charnockites with subordinate ultramafic-mafic enclaves, minor banded iron formations and exceedingly rare metapelitic lithologies. The charno-enderbites, charnockites and their retrogressed equivalents cover over $90 \%$ of the surface area in the NMZ (Ridley, 1992). The vast 
majority of these plutonic bodies are composed of massive to gneissic, tonalitictrondjhemitic granulites, interpreted to be the products of dry crustal melting at depth ([Ridley, 1992] and [Rollinson and Blenkinsop, 1995]). The most common mineral assemblage in the charnockites is Quartz-Plagioclase-K-feldspar-Biotite-Orthopyroxene with clinopyroxene, hornblende, and garnet variably present in a minority of samples (Ridley, 1992). Zircon U-Pb dating reveals the predominant charno-enderbitic magmatic phase was relatively long-lived with emplacement ages ranging from 2.75 to $2.58 \mathrm{Ga}$ (Berger et al., 1995). Nd $T_{\mathrm{DM}}$ model ages between 3.0 and 2.7 Ma (Berger et al., 1995) predate zircon ages, an artefact which Berger and Rollinson (1997) attribute to mixing between mantle derived melts and pre-existing crust. A suite of porphyritic, K-rich granites known as the Razi Suite intrude into the Northern Marginal Zone - Zimbabwe Craton boundary along the NLTZ (Rollinson and Blenkinsop, 1995). Zircon dating of micro-granites that cross-cut the Razi Suite and $\mathrm{U}-\mathrm{Pb}$ dating of zircons from rocks of the Razi Suite itself constrain their emplacement age and consequently the timing of the thrusting of the NMZ onto the ZC to between 2627 and $2547 \mathrm{Ma}$ ([Blenkinsop and Mkweli, 1992], [Mkweli et al., 1995] and [Frei et al., 1999]). Retrogression and deformation of the charno-enderbites is associated with late stage thrusting causing the development of a strong tectonic fabric, which is locally mylonitic, and the partial or complete replacement of pyroxenes by biotite and/or hornblende (Ridley, 1992).

\section{3. $P-T-t$ evolution}

\subsection{The Central Zone}

Watkeys (1979) and Broderick (1979) envisaged a twofold metamorphic evolution for the $\mathrm{CZ}$ beginning with a high-grade metamorphic event $\left(T>860^{\circ} \mathrm{C}, P>11 \mathrm{kbar}\right)$ which terminated at temperatures less than $330{ }^{\circ} \mathrm{C}$ after a series of folding and decompression events. Decompression textures are reported throughout the $\mathrm{CZ}$ by numerous workers (e.g. [Horrocks, 1983], [Harris and Holland, 1984] and [Droop, 1989]) and are thought to represent the rapid exhumation of the Archean crust after the collision of the Kaapvaal and Zimababwe cratons at ca. 2.6 Ga ([Watkeys, 1979], [Light, 1982] and [Harris and Holland, 1984]). More recently, (Holzer et al., 1998) and (Kroner et al., 1999) controversially recognised three phases of granulite facies metamorphism within the CZ. The earliest event $\left(\mathrm{M}_{1}\right.$ according to Kroner et al., 1999) at ca. 3.2 $\mathrm{Ga}$ is defined by various isotopic data ([Retief et al., 1990], [Tsunogae and Yurimoto, 1995], [Barton, 1996], [Jaeckel et al., 1997], [Kroner et al., 1998] and [Kroner et al., 1999]) and has been interpreted to correspond to an extensive magmatic event represented by the intrusion of the TTG Sand River granitoid suite precursors and the layered Messina Suite. Despite limited petrological indicators (Kroner et al., 1999) relate their $\mathrm{M}_{1}$ event to the first major structural event: $D_{1}$ - a strong non-coaxial deformation, which produced the first foliation in the SRG together with pervasive gneissose layering and isoclinal folding (Hofmann et al., 1998). The intrusion of the predominantly trondjhemitic gneiss precursors (upstream of the Causeway locality and still part of the Sand River granitoid suite) at ca. 3.2 Ga cuts the layering and isoclinal folding in the SRG thus demonstrating that $D_{1}$ must be older than 3.2 Ga (Kroner et al., 1999). Evidence for a second high-grade metamorphic event, $\mathrm{M}_{2}$ (essentially coeval with a $D_{2}$ non-coaxial deformation phase which produced folding 
and transposition of $D_{1}$-foliations to produce a second axial plane foliation and a new generation of folding and fabric formation in post- $D_{1}$ rocks (e.g. SRG sheath folds and type $1 \& 2$ interference patterns); Hofmann et al., 1998) at ca. 2.6-2.51 is based largely on $\mathrm{Pb}$ stepwise leaching dates from sillimanite and cogenetic garnet, obtained from metapelitic xenoliths within the Bulai Pluton (Holzer et al., 1998). Textural relationships indicate that sillimanite + cordierite + garnet are replacing andalusite which Holzer et al. (1998) interpret to represent a prograde reaction reflecting an anticlockwise low- $P /$ high- $T$ evolution. However, no petrological work on these samples was published. A late Archean high-grade metamorphic event is further supported by Kroner et al. (1999) who present a SHRIMP determined $\mathrm{Pb}^{207} / \mathrm{Pb}^{206}$ age of ca. $2560 \mathrm{Ma}$ for zircons found within melt veins of leucocratic garnetiferous gneiss. This age data therefore constrains the minimum age of anatectic melting and the maximum age of the deformation fabric in the rocks the melt veins intrude. Holzer et al. (1999) described three generations of such rocks, the oldest being intruded into the Bulai and the youngest cutting the Bulai. Coupled with single zircon ages for other granitoid gneisses (Kroner et al., 1999) it seems the $\mathrm{CZ}$ underwent several pulses of thermal disturbance associated with magmatism and tectono-metamorphism between 2.7 and 2.5 Ga (Holzer et al., 1998). McCourt and Armstrong (1998) present U-Pb (SHRIMP) data for zircons from syn- and post-tectonic granites in the western part of the Central Zone. Field and fabric relationships indicate that the syn-tectonic granites dated at ca. $2595+13$ Ma intruded during the Limpopo Orogeny which is interpreted to provide a minimum age constraint for the contractional phase of orogenesis.

The timing of last high-grade metamorphic event $\left(\mathrm{M}_{3}\right.$ - according to terminology of [Holzer et al., 1998] and [Kroner et al., 1999]) has in recent years been constrained by a number of studies. Metamorphic zircons from a metapelite of the BBC yield a $\mathrm{Pb}^{207} / \mathrm{Pb}^{206}$ evaporation mean age of $2026 \pm 7 \mathrm{Ma}$ (Jaeckel et al., 1997) and U-Pb analyses of metamorphic overgrowths on detrital zircon grains from a BBC quartzite yield an imprecise lower concordia intercept age of $2058 \pm 28 \mathrm{Ma}$ (Barton and Sergeev, 1997). More recently, (Buick et al., 2006) and (Mouri et al., this volume) have determined more precise ion probe data on monazite and metamorphic rims of single zircon, yielding a mean weighted ${ }^{207} \mathrm{~Pb}-{ }^{206} \mathrm{~Pb}$ ages of $\approx 2028 \mathrm{Ma} \pm 3 \mathrm{Ma}$ and $\approx 2006.5 \pm 8.0 \mathrm{Ma}$, respectively. This data supports the $\mathrm{Pb}$ stepwise leaching data obtained by Holzer et al. (1998) from garnet and titanite, which yield ages of $2010 \pm 17 \mathrm{Ma}$ and $2007 \pm 5 \mathrm{Ma}$, respectively. Monazite dating from within the same sample yields a concordant data point with an age of $2011 \pm$ Ma.

(Holzer et al., 1998) and (Kroner et al., 1999) relate the time constraints imposed by the aforementioned geochronological studies to the supposedly well-constrained $P-T$ conditions of the $\mathrm{M}_{3}$ event. A single granulite facies metamorphic episode is undisputedly characterised by a clockwise $P-T$ path (e.g. [Droop, 1989], [Hisada and Miyano, 1996] and [Zeh et al., 2004]). Spectacular reaction textures in garnetcorundum-sapphrine granulites document, according to Droop (1989), a progression from an early, coarse-grained, high-pressure, granulite-facies assemblages (designated $\mathrm{M}_{1}$ by Droop, 1989) to a late, low-pressure granulite-facies sub-assemblages $\left(\mathrm{M}_{2}\right.$ according to Droop, 1989). The symplectitic textures developed in these rocks are 
indicative of decompression. As these particular rocks have not been dated it is not possible to infer whether the $P-T$ path of Droop (1989) corresponds to a tectonometamorphic event in the either the Archean or Paleoproterozoic. Peak-metamorphic temperature estimates constrained by garnet-biotite thermometry on garnet interiors and phlogopite inclusions in corundum yield temperatures of ca. $850{ }^{\circ} \mathrm{C}$ (Droop, 1989). Peak pressure estimates in excess of $9.5 \mathrm{kbar}$ are implied (e.g. Droop, 1989) prior to a period of near-isothermal decompression (ITD) which terminated at pressures of 4-6 kbar ([Harris and Holland, 1984], [Droop, 1989] and [Hisada and Miyano, 1996]). The presence of late stage (2005 $\pm 8 \mathrm{Ma}$ ), undeformed melt leucosomes from within the SRG are interpreted by Jaeckel et al. (1997) to be the product of decompression melting. On the basis of phase relations in the FMASH system, microthermometry and textural evidence indicating gedrite was locally replacing orthopyroxene, Hisada and Miyano (1996) suggest ITD was followed by a period of near isobaric cooling (IBC), which commenced at $700-800{ }^{\circ} \mathrm{C}$ and 5-6 kbar (Fig. 2). Holzer et al. (1998) argue that the time of IBC is bracketed by a U-Pb intercept age of $1983 \pm 14 \mathrm{Ma}$ from five apatite fractions (Holzer et al., 1998) and ubiquitous $\mathrm{Rb}-$ Sr biotite cooling ages, which cluster around 1970 Ma (Barton et al., 1983).

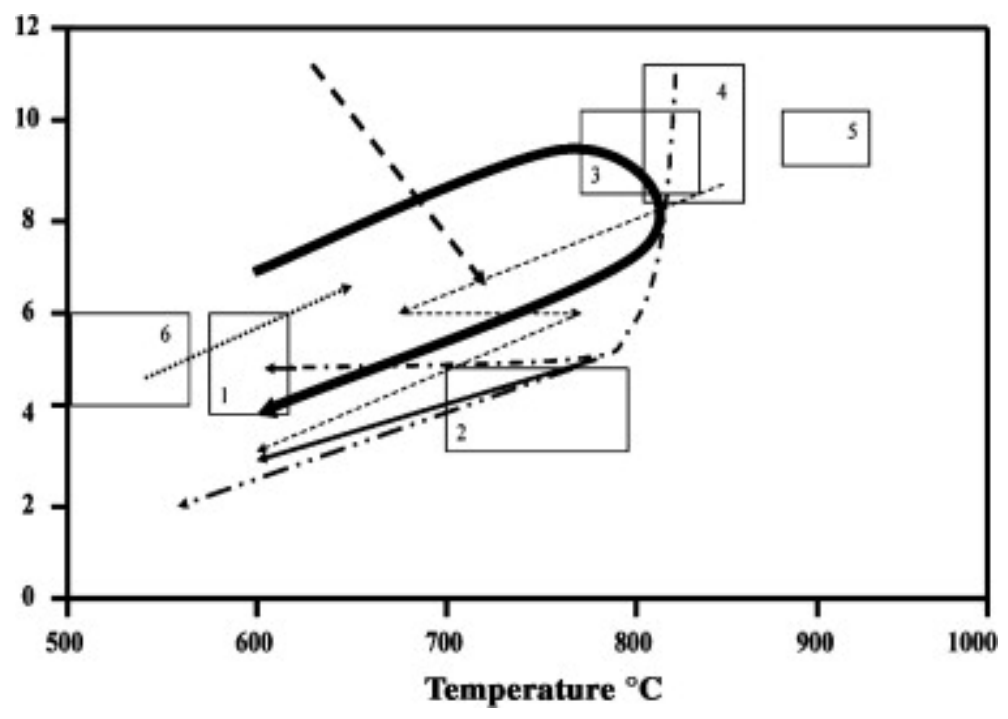

Fig. 2. A synopsis of $P-T$ paths and thermobarometric data from the $\mathrm{CZ}$ of the Limpopo belt modified from Zeh et al. (2005). The various arrowed lines indicate $P-T$ paths. Thick dashed line $=$ Klemd et al. (2003); Thin-dashed line = Boshoff et al. (2006). Dasheddotted line = Hisada and Miyano (1996); Thin solid line = Van Reenen et al. (2004); Thick line $=$ Zeh et al. (2004); Dotted line $=$ Zeh et al. (2005); Double dotted-dashed line $=$ Hisada et al. (2005). Boxes refer to thermobarometric estimates: 1 and $3=$ Perchuk et al. (2000), $2=$ Harris and Holland (1984); $4=$ Droop (1989), 5 and $6=$ Tsunogae and Van Reenen (2006).

Recent petrological studies (e.g. [Perchuk et al., 2000], [Klemd et al., 2003], [Van Reenen et al., 2004], [Zeh et al., 2004], [Zeh et al., 2005], [Hisada et al., 2005], [Perchuk et al., 2006] and [Boshoff et al., 2006]) suggest that major parts of the CZ did not 
undergo a $P-T$ path involving ITD and subsequent IBC (Fig. 2). The combined structural, petrographic and mineral chemistry data obtained by Van Reenen et al. (2004) for metapelites in the Baklykraal cross fold (10 km east of the Alldays area) indicate a distinct stage of deformation and mineral growth during post-peak metamorphic (ca. 2.0 Ga)evolution. Van Reenen et al. (2004) suggest the progression of two divariant reactions: (1) Garnet + Sillimanite + Quartz $=$ Cordierite and (2) Garnet $+\mathrm{Fe}$ Spinel $+\mathrm{H}_{2} \mathrm{O}=$ Biotite + Sillimanite + Quartz. Thermobarometric estimates and calculated mineral isopleths for the divariant equilibria define a decompression-cooling (DC) $P-T$ path traversing from $780^{\circ} \mathrm{C}$ at $5.7 \mathrm{kbar}$ to $600{ }^{\circ} \mathrm{C}$ at $3.3 \mathrm{kbar}$. A DC retrograde path was proposed earlier by Perchuk et al. (2000) who, on the basis of detailed microprobe profiling of garnet from a cordierite-bearing metapelite, defined a simultaneous $P$ and $T$ decrease from $800{ }^{\circ} \mathrm{C}$ at $9 \mathrm{kbar}$ to $600{ }^{\circ} \mathrm{C}$ at $4-5 \mathrm{kbar}$. Furthermore, metapelites from the Mahalapye Complex (MC) in the extreme south-western part of the CZ record well-developed metasomatic reaction textures indicating that the retrograde evolution was strongly dependent on fluid infiltration (Hisada et al., 2005). The retrograde $P-T$ path, defined using conventional thermobarometry and fluid inclusion data (Hisada et al., 2005) indicates DC from $770{ }^{\circ} \mathrm{C}$ at $5.5 \mathrm{kbar}$ to $560{ }^{\circ} \mathrm{C}$ and $2 \mathrm{kbar}$. The petrological investigations of Zeh et al. (2004) provide evidence to suggest that pelitic rocks of the $\mathrm{BBC}$ underwent a prograde evolution. Using quantitative phase diagrams ( $P-T$ pseudosections) in the system $\mathrm{CaO}-\mathrm{Na}_{2} \mathrm{O}-\mathrm{K}_{2} \mathrm{O}-\mathrm{TiO}_{2}-\mathrm{MnO}-\mathrm{FeO}-\mathrm{MgO}-$ $\mathrm{Al}_{2} \mathrm{O}_{3}-\mathrm{SiO}_{2}-\mathrm{H}_{2} \mathrm{O}$, Zeh et al. (2004) defined a clockwise $P-T$ path that displays a prograde $P-T$ increase from $600{ }^{\circ} \mathrm{C} / 7 \mathrm{kbar}$ to $780{ }^{\circ} \mathrm{C} / 9-10 \mathrm{kbar}$ (pressure peak) and $820^{\circ} \mathrm{C} / 8 \mathrm{kbar}$ (thermal peak), followed by a $P-T$ decrease to $600{ }^{\circ} \mathrm{C} / 4 \mathrm{kbar}$. The peak metamorphic $P-T$ conditions agree well with the peak $P-T$ estimates obtained by (Droop, 1989) and (Hisada and Miyano, 1996). However, the retrograde path, defined by matrix assemblages, garnet resorption textures, mineral zoning and diffusion patterns (Zeh et al., 2004) requires a simultaneous $P-T$ decrease, in excellent agreement with the DC paths defined by (Perchuk et al., 2000), (Van Reenen et al., 2004) and (Hisada et al., 2005) but in stark contrast to retrograde paths defined by ITD (e.g. [Droop, 1989] and [Hisada and Miyano, 1996]) and subsequent IBC (Hisada and Miyano, 1996). Additional evidence for prograde metamorphism during the $\mathrm{M}_{3}$ event is presented by Zeh et al. (2005) who calculated a petrogenetic grid in the model system $\mathrm{CaO}-\mathrm{FeO}-\mathrm{MgO}-\mathrm{Al}_{2} \mathrm{O}_{3}-\mathrm{SiO}_{2}-\mathrm{H}_{2} \mathrm{O}$ to derive $P-T$ pseudosections that were subsequently employed to infer a contemporaneous $P-T$ increase from $540{ }^{\circ} \mathrm{C} / 4.5 \mathrm{kbar}$ to $650{ }^{\circ} \mathrm{C} / 6.5 \mathrm{kbar}$ for grunerite-garnet-bearing amphibolites from the Endora Klippe (a tectono-metamorphic unit overlying the stratigraphic units of the Ventia Klippe, which surround the Ventia kimberlite pipes). This implies that rocks of the Endora Klippe never experienced granulite facies metamorphism. Moreover, the $P-T$ vector defined by Zeh et al. (2005) is similar to that obtained from the metapelitic BBC granulites (Zeh et al., 2004), but is shifted to lower pressures and temperatures. Ultimately, this led Zeh et al. (2005) to conclude that the rocks of the Endora Klippe form the roof zone of the granulite-facies rocks that predominate in the $\mathrm{CZ}$. Amphibolite facies conditions were first reported by Klemd et al. (2003) from rocks of the Venetia Klippe - a tectonostratigraphic unit which overlies the Krone metamorphic terrane and underlies the Endora Klippe in the area surrounding the Venetia kimberlite pipes (Barton et al., 2003). In complete contradiction to all previously determined $P-T$ paths for the $\mathrm{CZ}$, Klemd et al. (2003) infer a prograde pressure decrease 
and temperature increase from $630{ }^{\circ} \mathrm{C} / 13 \mathrm{kbar}$ to $720^{\circ} \mathrm{C} / 7-8 \mathrm{kbar}$. In light of this additional contradiction Zeh et al. (2005) concludes that either the prograde $P-T$ path inferred by Klemd et al. (2003) is erroneous, due to the application of equilibrium thermobarometry to rocks that are not in equilibrium or different rock units exist within the $\mathrm{CZ}$ that have undergone different $P-T$ evolutions and came into juxtaposition late during the tectono-metamorphic history.

Boshoff et al. (2006) obtained new field, structural, petrologic, and age data which is interpreted to reflect both Archean and Paleoproterozoic granulite facies tectonometamorphic events. A Paleoproterozoic $D_{3}$ event shear event is constrained to $2023 \pm 11 \mathrm{Ma}$ by Pb stepwise leaching of garnet that reflects the syn-tectonic crystallization of garnet-cordierite-sillimanite-biotite-quartz parageneses formed during shearing. The $D_{3}$ shearing event is superimposed upon earlier $D_{2}$ structures whose synkinematic minerals yield age dates ranging from ca. 2.6 to ca. 2.0 Ga. Boshoff et al. (2006) interpret these mixed ages to reflect an earlier, Archean granulite facies event with later Paleoproterozoic granulite facies overprint. The integrated petrological studies of (Perchuk et al., 2006) and (Boshoff et al., 2006) define two $P-T$ paths. Firstly, a decompression-cooling path from $850^{\circ} \mathrm{C}$ at $8.5 \mathrm{kbar}$ to $675^{\circ} \mathrm{C}$ at $6 \mathrm{kbar}$, which conforms the to nature of the $P-T$ paths defined by (Zeh et al., 2004), (Van Reenen et al., 2004) and (Zeh et al., 2005). Secondly, an isobaric (6 kbar) heating event from $\sim 675^{\circ} \mathrm{C}$ to $\sim 770{ }^{\circ} \mathrm{C}$ which was immediately followed by a DC path responsible for the uplift of the high-grade rocks toward the Earth's surface (Boshoff et al., 2006).

Tsunogae and Van Reenen (2006) infer an additional clockwise $P-T$ from orthopyroxene-sapphirine and garnet-staurolite assemblages that indicate peakmetamorphic conditions of $870-930{ }^{\circ} \mathrm{C}$ at $9-10 \mathrm{kbar}$ were attained prior to retrograde conditions of $500-570{ }^{\circ} \mathrm{C}$ at $4-6$ kbar. Furthermore, the author's suggest that the presence of $\mathrm{Mg}$-staurolite and corundum-garnet assemblages provides evidence for an earlier higher-pressure history which was possibly close to eclogite-facies metamorphism.

\subsection{The Southern Marginal Zone}

Stevens and Van Reenen (1992a) published a single, three-stage, clockwise $P-T$ path from field and petrographic relationships in metapelitic migmatites in the Bandelierkop Quarry (the type area of this rock type in the SMZ) (Fig. 3). The prograde $P-T$ path, defined by a series of fluid-absent melting reactions involving the incongruent breakdown of muscovite and biotite, records a period of prograde heating from $700{ }^{\circ} \mathrm{C}$ to $850^{\circ} \mathrm{C}$. Textural relationships indicating the production and preservation of sillimanite constrain the pressure during this heating event to within the sillimanite stability field (Stevens and Van Reenen, 1992a). The highest temperature reaction:

Biotite + Quartz + Plagioclase $=$ Orthopyroxene + Cordierite + Melt is deemed to have occurred at $850{ }^{\circ} \mathrm{C} / 9.5 \mathrm{kbar}$ (designated $\mathrm{M}_{1}$ by Stevens and Van Reenen, 1992a). These 'fossil thermobarometric' approximations are in reasonable agreement with the conventional thermobarometric estimates of Perchuk et al. $(1996)-800-850{ }^{\circ} \mathrm{C} / 7.5-$ $8.5 \mathrm{kbar}$ and Van den Berg and Huizenga (2001) - 750-825 ${ }^{\circ} \mathrm{C} / 6-8 \mathrm{kbar}$. The direct age of prograde metamorphism in the Bandelierkop Quarry is constrained by $\mathrm{U} / \mathrm{Pb}$ dating of 
monazite and zircon evaporation $\mathrm{Pb}^{207} / \mathrm{Pb}^{206}$ dating of melt leucosomes, which yield ages of $2691 \pm 7 \mathrm{Ma}$ and $2643 \pm 1 \mathrm{Ma}$, respectively (Kreissig et al., 2001). Metapelites of the SMZ also preserve textural evidence to suggest that peak $\mathrm{M}_{1}$ mineral assemblage are overprinted by pressure-driven garnet consuming reactions ([Van Reenen, 1983], [Stevens and Van Reenen, 1992a] and [Stevens and Van Reenen, 1992b]). The divariant reactions responsible for the consumption of garnet and the production of cordierite, in rocks of suitable composition at the Bandelierkop Quarry, are

Garnet + Quartz + Sillimanite $=$ Cordierite $\left(\mathrm{M}_{2 \mathrm{a}}\right)$ and

Garnet + Quartz $=$ Cordierite + Orthopyroxene $\left(\mathrm{M}_{2 \mathrm{~b}}\right)$. These reactions are interpreted to reflect a period of ITD - the $\mathrm{M}_{2}$ event of the single clockwise $P-T$ loop defined by Stevens and Van Reenen (1992a).

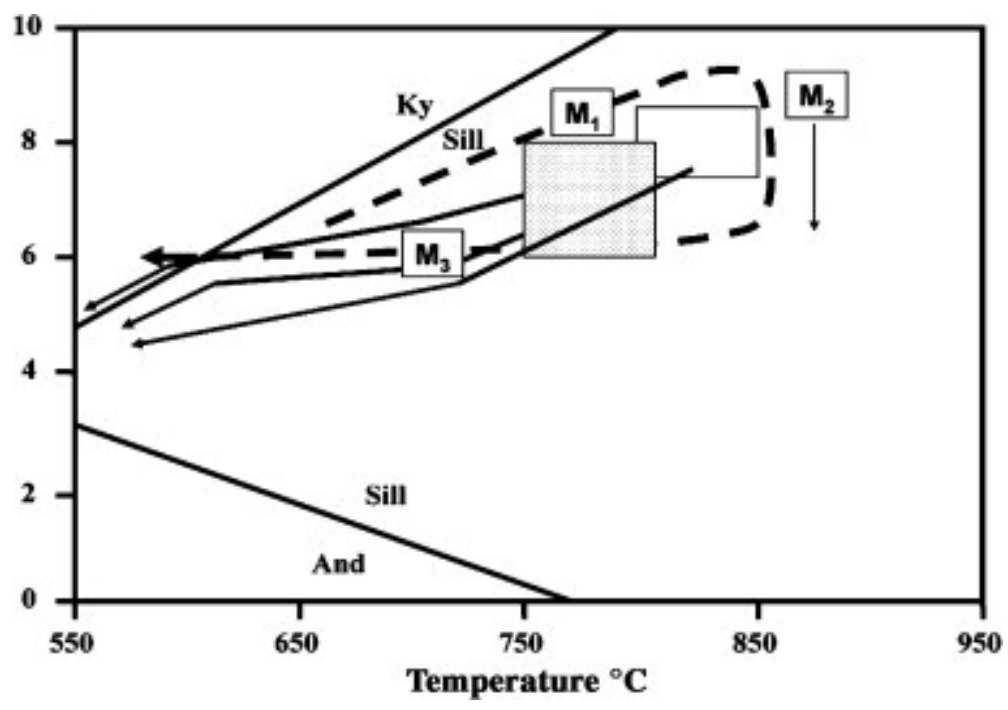

Fig. 3. A synopsis of the $P-T$ conditions from the SMZ. The thick dashed line indicates the clockwise $P-T$ path defined by Stevens and Van Reenen (1992a). The thin solid lines represent the cooling paths delineated by Perchuk et al. (2000). The dashed box represents the $P-T$ conditions estimated by Van den Berg and Huizenga (2001). The striped box represents the $P-T$ conditions estimated by Perchuk et al. (1996). The $\mathrm{Al}_{2} \mathrm{SiO}_{5}$ reaction boundaries were calculated using THERMOCALC (Holland and Powell, 1998).

The final retrograde stage of the $P-T$ loop defined Stevens and Van Reenen (1992a) corresponds to a widespread rehydration event $\left(\mathrm{M}_{3}\right)$ involving the following reactions: Cordierite + K-feldspar + Melt $=$ Biotite + Kyanite + Quartz $\left(\mathrm{M}_{3 \mathrm{a}}\right)$; Cordierite $+\mathrm{H}_{2} \mathrm{O}=$ Gedrite + Kyanite $\left(\mathrm{M}_{3 \mathrm{~b}}\right)$; Orthopyroxene $+\mathrm{H}_{2} \mathrm{O}=$ Anthophyllite $\left(\mathrm{M}_{3 \mathrm{c}}\right)$. Reactions $\mathrm{M}_{3 \mathrm{a}}$ and $\mathrm{M}_{3 \mathrm{~b}}$ occur throughout the $\mathrm{SMZ}$ in all cordierite-bearing lithologies, while the $\mathrm{M}_{3 \mathrm{c}}$ reaction is restricted to the rehydrated subzone in the south of the SMZ where it defines the ortho-amphibole isograd ([Van Reenen, 1986] and [Stevens and Van Reenen, 1992a]). Garnet-biotite thermometry and fluid inclusion data indicate reactions $\mathrm{M}_{3 \mathrm{~b}}$ and $\mathrm{M}_{3 \mathrm{c}}$ took place at $600{ }^{\circ} \mathrm{C}$ and $6 \mathrm{kbar}$ indicating a period of cooling 
post-ITD (Van Reenen, 1986). Perchuk et al. (2000) postulated that the retrograde paths of SMZ rocks are strongly dependent on the structural setting and take the form of either $\mathrm{DC}$ or, for samples that are located close to the boundary of the SMZ with the KC, a combination of DC followed by IBC. This view is largely supported by the work of Smit et al. (2001) who demonstrated metapelites from the northern thrust sheet of the HRSZ record a DC path with $\mathrm{dT} / \mathrm{d} P$ of ca. $70{ }^{\circ} \mathrm{C} \mathrm{kbar}^{-1}$, whereas metapelites with a similar bulk composition from the southern thrust sheet record an IBC path with a $\mathrm{d} T / \mathrm{d} P$ of 120 $140{ }^{\circ} \mathrm{C} \mathrm{kbar}^{-1}$. Decompression $\left(\mathrm{M}_{2}\right)$ and cooling to amphibolite-facies temperatures $\left(\mathrm{M}_{3}\right)$ is thus associated with the southwards thrusting $\left(D_{2}\right)$ of the granulites along the HRSZ onto the relatively cold KC ([Smit et al., 1992] and [Smit et al., 2001]). The timing of the $D_{2}$ event and consequently $\mathrm{M}_{2}-\mathrm{M}_{3}$ has been directly constrained by $\mathrm{Ar}-\mathrm{Ar}$ dating of amphiboles in amphibolites from the HRSZ, which yields maximum ages constraints ranging from 2650 to $2620 \mathrm{Ma}$ (Kreissig et al., 2001).

\subsection{The Northern Marginal Zone}

Rollinson (1989) applied garnet-orthopyroxene thermobarometry to charno-enderbititc rocks of tonalitic composition to demonstrate peak granulite facies metamorphism varied across the NMZ. In the western regions of the NMZ peak-metamorphic conditions are constrained to be $825 \pm 50{ }^{\circ} \mathrm{C}$ at $5 \pm 1 \mathrm{kbar}$, conversely, in the east, peak-metamorphic conditions of $850 \pm 50^{\circ} \mathrm{C}$ and $8.4 \pm 1 \mathrm{kbar}$ indicate the NMZ suffered differential uplift along an anticlockwise $P-T$ path ([Rollinson, 1989] and [Kamber and Biino, 1995]). In contrast, Tsunogae et al. (1992) defined a clockwise P-T path (Fig. 4) from metapelitic gneiss, which preserved a peak-metamorphic assemblage (Garnet-OrthopyroxenePlagioclase-Quartz) and a retrograde assemblage (Garnet-Cordierite-SillimaniteQuartz). Peak-metamorphic conditions were estimated to be $740-790{ }^{\circ} \mathrm{C}$ at $7.5-7.9 \mathrm{kbar}$, whereas the apparent retrograde assemblage yielded $P-T$ estimates in the range of 630 $660^{\circ} \mathrm{C}$ at 3.8-4.5 kbar (Tsunogae et al., 1992). Furthermore, Tsunogae et al. (1992) calculated a host of variable $P-T$ conditions ranging from $550-630{ }^{\circ} \mathrm{C}$ at $2.5-3.7 \mathrm{kbar}$ and $720-760{ }^{\circ} \mathrm{C}$ at $6.5-7.4 \mathrm{kbar}$ for charnockites using a Garnet-OrthopyroxenePlagioclase-Quartz assemblage. Mafic granulites containing the assemblage Orthopyroxene-Clinopyroxene-Plagioclase-Hornblende preserve coronas of Orthopyroxene-Magnetite-Quartz symplectite replacing hornblende. Rollinson and Blenkinsop (1995) interpret these textures to reflect two granulite facies metamorphic events, the first of which produced the Orthopyroxene-Clinopyroxene-PlagioclaseHornblende assemblage whilst the second event was responsible for the dehydration of hornblende and the development of the symplectitic coronas. The timing and exact nature of these proposed events are not yet constrained. 


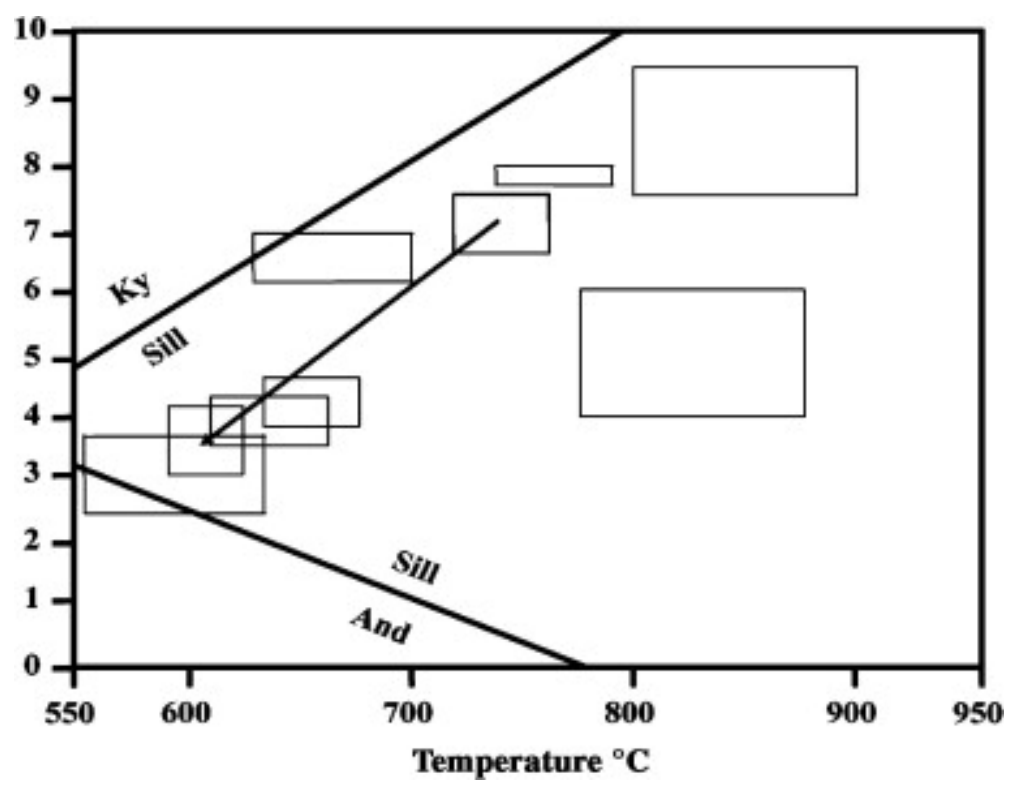

Fig. 4. A synopsis of the $P-T$ conditions from the NMZ. Striped boxes indicate $P-T$ conditions for metapelites (after Tsunogae et al., 1992). Clear boxes indicate $P-T$ conditions for charnockitic gneiss (after Tsunogae et al., 1992). Dotted boxes indicate $P-$ $T$ conditions for charno-enderbites of tonalitic composition (after Rollinson, 1989). The dashed arrow indicates the $P-T$ path proposed by Tsunogae et al. (1992). The $\mathrm{Al}_{2} \mathrm{SiO}_{5}$ reaction boundaries were calculated using THERMOCALC (Holland and Powell, 1998).

The highly variable peak-metamorphic conditions ([Rollinson, 1989], [Tsunogae et al., 1992] and [Rollinson and Blenkinsop, 1995]) and the scattered zircon age dates for plutonism ca. 2.7-2.58 Ga (Berger et al., 1995; Kamber et al., 1995b) led (Rollinson and Blenkinsop, 1995) and (Kamber and Biino, 1995) and Kamber et al. (1995b) to suggest that either the whole NMZ underwent a prolonged period (ca. $100 \mathrm{Ma}$ ) of high-grade, granulite-facies metamorphism associated with extensive charno-enderbitic magmatism, or the high-grade metamorphic event was not synchronous over the entire terrain. Geochemical analysis by Kramers et al. (2001) revealed rocks of the NMZ have anomalously high concentrations of K, Th and U. Subsequent geotherm modelling, incorporating minimum basal heat flux and crustal thickening parameters implies the NMZ had a large internal capacity for generating heat; a feature Kramers et al. (2001) relate to repeated high-grade metamorphic events associated with prolonged magmatic activity. An additional tectono-metamorphic event, with peak conditions estimated at $600-650{ }^{\circ} \mathrm{C} / 6.5 \mathrm{kbar}$, is reported for the southern half the NMZ by (Kamber et al., 1995a) and (Kamber et al., 1995b). The timing of this event is constrained by Ar-Ar dating of metamorphic hornblende from amphibolites to be ca. 2.0 Ga ([Kamber et al., 1995a] and [Kamber et al., 1995b]). 


\section{Discussion: implications for tectonic models}

The vast majority of published literature indicate the $P-T-t$ evolution of the $\mathrm{CZ}$ of the Limpopo belt forms a single clockwise loop (e.g. [Harris and Holland, 1984], [Droop, 1989], [Hisada and Miyano, 1996] and [Zeh et al., 2004]), implying peak-metamorphic temperatures were attained after tectonic thickening had commenced. According to Holzer et al. (1998) crustal thickening was initiated at ca. 2.0 Ga during the collision of the Kaapvaal and Zimbabwe cratons (Holzer et al., 1998). Holzer et al. (1998) argue shearing and contemporaneous thrusting caused successive stacking of the rock units in a NW-directed stress regime, whereas the structural data of (McCourt and Vearncombe, 1987) and (McCourt and Vearncombe, 1992) implies an ENE directed simple shear regime. Subhorizontal and down-dip lineations in both the PSZ and TSZ ([McCourt and Vearncombe, 1987] and [McCourt and Vearncombe, 1992]) are consistent with a dextral sense of movement that Holzer et al. (1998) relate to transpressional tectonics. However, this is only a selective analysis of the published literature as (McCourt and Vearncombe, 1987) and (McCourt and Vearncombe, 1992) actually advocate a sinistral sense of movement for the $070^{\circ}$ trending shear zones in the PSZ.

Thermobarometric estimates indicate rocks of the $\mathrm{CZ}$ were buried to depths of $\sim 35 \mathrm{~km}$ and subsequent re-equilibration of the geothermal gradient superimposed a granulitefacies mineralogy onto the large scale structures associated with crustal thickening. This model requires contemporaneous burial and heating which is in excellent agreement with the prograde $P-T$ path $\left(600^{\circ} \mathrm{C}\right.$ at $7 \mathrm{kbar}$ and $780{ }^{\circ} \mathrm{C}$ at $\left.9-10 \mathrm{kbar}\right)$ determined by Zeh et al. (2004) and, moreover, the prograde pressure decrease and temperature increase inferred by Zeh et al. (2004) indicates that thermal re-equilibration continued after tectonic thickening had ceased and initial uplift had started. The duration of the whole metamorphic cycle, bracketed by ages of ranging from ca. 2058 to $2007 \mathrm{Ma}$ (e.g. [Jaeckel et al., 1997], [Barton and Sergeev, 1997], [Holzer et al., 1998] and [Kroner et al., 1999]) and cooling ages of ca. 1970-1983 Ma ([Barton et al., 1983] and [Holzer et al., 1998]) is interpreted to lie between 24 and $90 \mathrm{Ma}$. On the other hand, McCourt and Armstrong (1998) argue that whilst a high-grade metamorphic event does appear to have taken place at ca. 2.0 Ga it did not result from the collision of the Kaapvaal and Zimbabwe Cratons. (Roering et al., 1992) and (McCourt and Armstrong, 1998) suggest that the collision was an Archean event. McCourt and Armstrong (1998) argue that the 2.0 Ga ages determined by other workers may reflect a reworking of Archean shear zones, possibly during the final exhumation of the $\mathrm{CZ}$ This reactivation maybe related to the Eburnean-aged southward-vergent 2.0 Ga Magondi Orogen on the northwestern margin of the ZC ([McCourt and Armstrong, 1998] and [Bumby et al., 2001]).

Despite the different interpretations on the timing of the collisional event, the peakmetamorphic and prograde conditions within the $\mathrm{CZ}$ thus far remain fairly robust and relatively undisputed. However, the subsequent uplift and cooling history of the $\mathrm{CZ}$ remains another bone of contention. There are currently two contrasting schools of thought. Firstly, the exhumation paths of (Droop, 1989) and (Hisada and Miyano, 1996) imply ITD of several kbars. During this decompression, rocks moved upward and spread outward onto the adjacent cratons from the zone of thickened crust along the inward- 
dipping TSZ to the north and the PSZ in the southern part of the CZ ([Roering et al., 1992] and [Holzer et al., 1998]). This regional 'pop-up' model, which is based on the kinematics in the NLTZ and the HRSZ, both of which are Archean structures, implies exhumation was, in part, controlled by the shear zones that bind the CZ. Post-ITD cooling paths are deemed to reflect IBC at pressures of 5-6 kbar (Hisada and Miyano, 1996). In contrast, however, the retrograde $P-T$ paths of (Van Reenen et al., 2004), (Zeh et al., 2004), (Zeh et al., 2005), (Hisada et al., 2005) and (Boshoff et al., 2006) imply simultaneous pressure and temperature decreases which argue against a simple 'pop-up' model. Zeh et al. (2004) calculated a linear cooling rate of $7{ }^{\circ} \mathrm{C} \mathrm{My}^{-1}$ and a linear exhumation rate of about $0.3 \mathrm{~mm} \mathrm{a}^{-1}$. The assumptions inherent in their calculations were: (1) The metamorphic zircon dated by Jaeckel et al. (1997) ca. $2027 \pm 6 \mathrm{Ma}$, grew near to the thermal climax $\left(820^{\circ} \mathrm{C} / 8 \mathrm{kbar}\right)$ and (2) the lithostatic pressure gradient was 270 bar $\mathrm{km}^{-1}$. Coupled with petrological evidence supporting a retrograde DC path, Zeh et al. (2004) argue that exhumation, which lasted for $45 \mathrm{Myr}$, was maintained by erosional tectonics (cf. England and Thompson, 1984). The tectonic dichotomy of the $\mathrm{CZ}$ is further complicated with the additional contradictory prograde $P-T$ path inferred by Klemd et al. (2003). The apparent disparity in the aforementioned $P-T$ work leads to one of two conclusions, either (1) some of the $P-T$ conditions derived for parts of the $\mathrm{CZ}$ are erroneous, due to the application of equilibrium thermobarometry to mineral assemblages that are not in equilibrium or (2) different rock units exist within the CZ that have undergone different $P-T$ evolutions and came into juxtaposition late during the tectonometamorphic history (Zeh et al., 2004). Assuming the most unfavourable of circumstances, that the latter is true, future $P-T-t$ paths delineating tectonic histories cannot be constructed using data from separate petrological and geochronology studies. In order to address and potentially resolve these pertinent contradictions, detailed petrological investigations need to be fully-integrated with geochronological data from the same sample suite. Furthermore, future petrological studies should constrain $P-T$ paths for a single rock sample by calculating $P-T$ pseudosections. This approach overcomes many of the problems associated with the application of conventional thermobarometry to high-grade metamorphic terranes (e.g. [Harley, 1989] and [White et al., 2002]) and consequently they may resolve the nature of $P-T$ paths for large sections of the Limpopo Belt.

Evidence for the earlier ca. 3.1-03.2 Ga metamorphic event ([Holzer et al., 1998] and [Kroner et al., 1999]) is less robust, especially on petrological grounds. The field relationships concerning the tectono-metamorphic history of the early-Archean event are essentially erased by the two subsequent high-events (e.g. [Van Reenen et al., 1992] and [Holzer et al., 1998]). Although no hard petrological evidence exists for the earlyArchean event, structural analysis coupled with geochronological data ([Hofmann et al., 1998], [Holzer et al., 1998] and [Kroner et al., 1999]) indicates a major fabric forming event $\left(D_{1}\right)$ occurred prior to the intrusion of the most prevalent granitoid gneisses and their associated deformation $\left(D_{2}\right)$ at ca. 2.7-2.5. The second metamorphic event at ca. 2.65-2.52 is constrained by structural analysis, demonstrating that $D_{2}$ cuts and folds $D_{1}$ (Hofmann et al., 1998), and by the dating of metamorphic silicates and contemporaneous magmatic bodies (see above for details; [Holzer et al., 1998] and [Kroner et al., 1999]). Holzer et al. (1998) infers that the second metamorphic event at ca. 2.65-2.52 evolved 
along an anticlockwise $P-T$ path. This assertion is based largely on textural evidence implying sillimanite is replacing andalusite in metapelitic xenoliths from the Bulai intrusion and from unpublished $P-T$ work on garnetiferous metapelites from the 'Three Sisters' area (20 km WNW of Messina). Zeh et al. (2005) argue that the dates for the second metamorphic event do not necessarily reflect the time of a major regional tectonometamorphic event but may actually represent a contact metamorphic overprint. The key to the second metamorphic event clearly rests on these contentious garnet-bearing metapelites and xenoliths mentioned by Holzer et al. (1998). It begs the question of why detailed petrological investigations have not been undertaken on the samples from the 'Three Sisters' area or why $P-T$ conditions for the metapelitic xenoliths were not reported? In contrast to the anticlockwise metamorphic evolution at ca. 2.65-2.52, Boshoff et al. (2006) define a clockwise $P-T$ evolution with an age that is constrained by the dating of syn-tectonic minerals. Although the dates are mixed (ranging from 2.0 to 2.6) they do provide evidence for an earlier ca. $2.6 \mathrm{Ga}$ event. The $P-T$ path associated with this event is identical to that obtained by Zeh et al. (2004), thus suggesting that both authors modelled the same metamorphic event. However, Zeh et al. (2004) relate their P$T$ path to the $2.0 \mathrm{Ga}$ event. Furthermore, the clockwise evolution defined by Tsunogae and Van Reenen (2006) is interpreted to reflect high-pressure metamorphism during the collision of the Kaapvaal and Zimbabwe cratons at ca. 2.6 Ga. These disparities once again highlight the critical issue of integrating petrological and geochronological studies. Despite the petrological uncertainties pertaining to the exact nature of the metamorphism in the $\mathrm{CZ}$ around 2.65-2.52 Ga there are broad temporal correlations regarding the predominant magmatic activity across the zones of the Limpopo Belt. Granitoid magmatism in the $\mathrm{CZ}$ at ca. $2.65-2.52$ is broadly contemporaneous with charnoenderbitic plutonism in the NMZ at ca. 2.75-2.58. Kroner et al. (1999) conclude that it is too early to speculate whether there was a common geodynamic cause for the emplacement of granitoid rocks and associated high-grade metamorphism in both zones. Rollinson and Blenkinsop (1995) suggest that the scattered zircon age dates and heterogeneous $P-T$ conditions recorded from the NMZ can be interpreted in one of two ways: (1) there were two distinct crustal events; one involving crustal thickening and associated granulite-facies metamorphism and the other metamorphic event occurring some $250 \mathrm{Ma}$ later was associated with the intrusion of the RS or (2) There was a continuum of magmatism, granulite-facies metamorphism and compression culminating in the emplacement of the RS and uplift at ca. $2630 \mathrm{Ma}$ (Rollinson and Blenkinsop, 1995). The latter interpretation is favoured by Kramers et al. (2001) who on the basis of geochemical analysis and subsequent geotherm modelling concludes that the anomalous basal heat flux recorded in the NMZ is a more likely cause for extensive intracrustal crustal melting than tectonic thickening, as it adequately explains the metamorphic characteristics, the charno-enderbitic magmatism and the variable $\mathrm{Nd} T_{\mathrm{DM}}$ ages. The relatively high-pressures (4-8 kbar) recorded by $P-T$ investigations ([Rollinson, 1989] and [Tsunogae et al., 1992]) can be explained by magmatic crustal thickening alone (e.g. [Kamber and Biino, 1995] and [Kramers et al., 2001]). However, Rollinson and Blenkinsop (1995) envisage that extensive plutonic rise will be accompanied by subsidence around the margins of the plutons, where supracrustal rocks could be brought to lower crustal levels and further magmatic upwelling in a compressional regime would be responsible for returning these rocks to the surface. 
The geochemical evidence ([Berger et al., 1995], [Rollinson and Blenkinsop, 1995] and [Berger and Rollinson, 1997]) suggests that the charno-enderbites, which cover $90 \%$ of the surface area of the NMZ, were derived by the partial melting of a mafic source. Kramers et al. (2001) speculates that on the whole the evidence would not conflict with either a plume or northward dipping subduction zone setting, in which the NMZ constituted a continental margin situated at the edge of the craton and thrusting along the NLTZ at ca. 2.6 Ga could possibly be explained by collision or slab break-off (Yoshioka and Wortel, 1995). (Rollinson and Blenkinsop, 1995) and (Kramers et al., 2001) advocate that tectono-metamorphism in the NMZ did not result from the collision of the Zimbabwe and Kaapvaal Cratons, as previously suggested by Roering et al. (1992). Tectonic speculations aside, the granulite-facies metamorphism in the $\mathrm{CZ}$ was contemporaneous with amphibolite-facies metamorphism in the southern part of the NMZ at ca. $2.0 \mathrm{Ga}$ (Kamber et al., 1995b). Furthermore, structural analysis by Kamber et al. (1995b) along a $43 \mathrm{~km}$-long profile reveals the accompanying deformation event in the NMZ can be classified as transpressional, which conforms to the structural data cited by Holzer et al. (1998) for the ca. $2.0 \mathrm{Ga}$ tectono-metamorphic episode in the CZ. This structural and geochronological compatibility implies that the ca. 2.0 Ga metamorphic event in the southern half of the NMZ may also be genetically related to the ca. 2.0 Ga metamorphism in the CZ. However, the same interpretative problems still exist. This may have been related the collision of the Kaapvaal and Zimbabwe cratons (e.g. Holzer et al., 1998) or it may represent reactivation along shear zones (e.g. McCourt and Armstrong, 1998). What is curious about either scenario is why there is no evidence of 2.0 Ga metamorphic event in the SMZ?

A three-stage clockwise $P-T$ evolution ([Stevens and Van Reenen, 1992a] and [Stevens and Van Reenen, 1992b]) for the SMZ at ca. 2.7-2.6 Ga ([Kreissig et al., 2001] and [Smit et al., 2001]) is deemed to reflect a continent-continent type collision (Van Reenen et al., 1990). Magmatic activity in the SMZ during this period is also broadly contemporaneous with magmatism in both the $\mathrm{CZ}$ and NMZ, which strongly suggests a causal link between all three zones ([Holzer et al., 1998] and [Kroner et al., 1999]). Metamorphism associated with prevalent magmatic activity in the NMZ at ca. 2.75-2.58 Ga and at ca. 2.6-2.52 Ga in the $\mathrm{CZ}$, is characterised, by anticlockwise $P-T$ paths (e.g. [Kamber and Biino, 1995] and [Holzer et al., 1998]) which is in direct contradiction to the $P-T$ evolution of the SMZ. However, the clockwise $P-T$ path defined by Boshoff et al. (2006) at ca. $2.6 \mathrm{Ga}$ is in good agreement with the clockwise evolution of the SMZ during the same time period and thus it may reflect a common causal link, which may be interpreted to be the collision of the Kaapvaal and Zimbabwe Cratons. A correlation of high-temperature events in all three zones of the Limpopo Belt during the late Archean can neither be denied nor justified convincingly (Holzer et al., 1998). Any tectonic framework invoked to explain the evolution of the Limpopo Belt must be consistent with the available $P-T-t$ data. At present a coherent and inter-related tectonic model is not plausible considering the conflicting $P-T$ paths and the timing of the metamorphic events. Consequently, wellconstrained $P-T$ conditions coupled with fully-integrated geochronological evidence are required in order to produce reliable $P-T-t$ paths for each of the zones that can employed to decipher the tectono-metamorphic history of the Limpopo Belt. We propose to address 
these pertinent issues in pending research, which will be published in international journals.

\section{Summary and conclusions}

(1) Geochronological, structural and metamorphic evidence collectively indicate that the $\mathrm{CZ}$ underwent tectono-metamorphism at ca. 2.0 Ga. However, the tectonic implications of this event are matter of dispute. There are currently two contrasting schools of thought: (a) The ca. 2.0 Ga metamorphic event represents a transpressive orogeny that was initiated by the collision of the Kaapvaal and Zimbabwe cratons or (b) The cratons had collided earlier at ca. 2.6 Ga and the later ca. 2.0 Ga granulite metamorphism is an overprint representing reworking along Archean shear zones. Deformation and metamorphism consistent with a $2.0 \mathrm{Ga}$ event are observed in the southern part of the NMZ but are completely absent from the SMZ.

(2) Contrasting retrograde paths in the $\mathrm{CZ}$ indicate that either different units exist within the $\mathrm{CZ}$ that underwent different $P-T$ paths or some $P-T$ work is erroneous due to the application of equilibrium thermodynamics to mineral assemblages that are not in equilibrium. Post-peak-metamorphic conditions reveal contrasting retrograde paths implying either near-isothermal decompression and isobaric cooling associated with a 'pop-up' style of exhumation or steady decompression-cooling linked to exhumation controlled by erosion.

(3) The $\mathrm{CZ}$ is characterised by an earlier metamorphic event at ca. 2.6-2.52 Ga. However, the nature of the $P-T$ paths defined by different workers (clockwise versus anticlockwise) implies contrasting evolutions. A high-grade granulite facies metamorphic event evolving along a clockwise $P-T$ path at ca. 2.6 Ga may be interpreted to have resulted from the collision of the Kaapvaal and Zimbabwe Cratons. The anticlockwise evolution advocated by some workers during this same time period may represent the localised thermal influence of magmatic bodies.

(4) Granitoid magmatism is broadly contemporaneous in all three zones at ca. 2.7-2.5 suggesting a possible causal geodynamic link.

(5) $P-T$ contrasts between and within the respective zones prevents, at present, the construction of a coherent and inter-related tectonic model that can account for all of the available evidence.

(6) Detailed and fully-integrated petrological and geochronological studies are required to produce reliable $P-T-t$ paths that may resolve some of these pertinent contradictions. 


\section{References}

Barton, 1996 J.M. Barton Jr., The Messina layered intrusion, Limpopo belt, South Africa: an example of in-situ contamination of Archean anorthosite complex by continental crust, Precambrian Research 78 (1996), pp. 139-150.

Barton and Sergeev, 1997 J.M. Barton and S. Sergeev, High precision, U-Pb analyses of single grains of zircon from quartzite in the Beit Bridge Group yield a discordia, South African Journal of Geology 100 (1997), pp. 37-41.

Barton and Van Reenen, 1992 J.M. Barton and D.D. Van Reenen, When was the Limpopo Orogeny? Precambrian Research 55 (1992), pp. 7-16.

Barton et al., 1983 Barton, J.M., Ryan, B., Fripp, R.E.P., 1983. Rb-Sr and U-Th-Pb studies of the Sand River Gneisses, central zone, Limpopo mobile belt. In: Van Biljon, W.J., Legg, J.H. (Eds.), The Limpopo belt, Special Publication 8, Geological Society of South Africa, Johannesburg, pp. 9-18.

Barton et al., 1992 J.M. Barton, R. Doig, C.B. Smith, F. Bohlender and D.D. Van Reenen, Isotopic and REE characteristics of the intrusive charnoenderbite and enderbite geographically associated with the Matok Pluton, Limpopo belt, Southern Africa, Precambrian Research 55 (1992), pp. 451-567.

Barton et al., 1994 J.M. Barton, L. Holzer, B. Kamber, R. Doig, J.D. Kramers and D. Nyfeler, Discrete metamorphic events in the Limpopo belt, Southern Africa: implications for the application of $P-T$ paths in complex metamorphic terranes, Geology 22 (1994), pp. 1035-1038.

Barton et al., 2003 J.M. Barton, W. Barnett and E.S. Barton et al., The geology of the area surrounding the Venetia kimberlite pipes, Limpopo belt, South Africa: a complex assembly of terranes and granitoid magmatism, South African Journal of Geology 106 (2003), pp. 109-128.

Berger and Rollinson, 1997 M. Berger and H. Rollinson, Isotopic and geochemical evidence for crustal-mantle interaction during late Archean crustal growth, Geochemistry and Cosmochemistry Acta 61 (1997), pp. 4809-4829.

Berger et al., 1995 M. Berger, J.D. Kramers and T.F. Nagler, An Archaean high grade province adjacent to a granite greenstone terrain: geochemistry and geochronology of charnoenderbites in the Northern Marginal Zone of the Limpopo belt, Southern Africa and genetic models, Schweizerische Mineralogische und Petgrographische Miteilungen 75 (1995), pp. 17-42.

Blenkinsop and Mkweli, 1992 Blenkinsop, T.G., Mkweli, S., 1992. The relation between the Zimbabwe Craton and the North Marginal Zone of the Limpopo. In: Third Symposium on Science and Technology, Research Council of Zimbabwe. 
Bohlender et al., 1992 F. Bohlender, D.D. Van Reenen and J.M. Barton, Evidence for metamorphic and igneous charnockites in the Southern Marginal Zone of the Limpopo belt, South Africa, Precambrian Research 55 (1992), pp. 429-449.

Boshoff et al., 2006 R. Boshoff, D.D. Van Reenen, J.D. Kramers, C.A. Smit, L.L. Perchuk and R. Armstrong, Geologic history of the central zone of the Limpopo complex: the West Alldays Area, The Journal of Geology 114 (2006), pp. 699-716.

Brandl, 1983 G. Brandl, Geology and geochemistry of various supracrustal rocks of the Beit bridge complex east of Messin, Special Publication of the Geological Society of South Africa 8 (1983), pp. 103-112.

Broderick, 1979 Broderick, T.J., 1979. Explanation of the geological map of the country South of Nuanetsi and Beitbridge Districts. Rhodesian Geological Survey Short Report 46.

Buick et al., 2006 I.S. Buick, J. Hermann, I.S. Williamsb, R.G. Gibson and D. Rubatto, A SHRIMP U-Pb and LA-ICP-MS trace element study of the petrogenesis of garnetcordierite-orthoamphibole gneisses from the Central Zone of the Limpopo belt, South Africa, Lithos 88 (2006), pp. 150-172.

Bumby et al., 2001 A.J. Bumby, P.G. Eriksson, R. van der Merwe and J.J. Brumer, Shear-zone controlled basins in the Blouberg area, Northern Province, South Africa: synand post-tectonic sedimentation relating to c. 2.0 Ga reactivation of the Limpopo belt, Journal of African Earth Sciences 33 (2001), pp. 445-461.

Chavagnac et al., 2001 V. Chavagnac, J.D. Kramers, T.F. Nagler and L. Holzer, The behaviour of $\mathrm{Nd}$ and $\mathrm{Pb}$ isotopes during the $2.0 \mathrm{Ga}$ migmatization in paragneisses of the Central Zone of the Limpopo belt (South Africa and Botswana), Precambrian Research 112 (2001), pp. 51-86.

Coward, 1983 M.P. Coward, Some thoughts on the tectonics of the Limpopo belt, Special Publication of the Geological Society of South Africa 8 (1983), pp. 175-180.

Droop, 1989 G.T.R. Droop, Reaction history of garnet-sapphirine granulites and conditions of Archaean high-pressure granulite-facies metamorphism in the Central Limpopo mobile belt, Zimbabwe, Journal of Metamorphic Geology 7 (1989), pp. 383403.

Du Toit et al., 1983 M.C. Du Toit, D.D. Van Reenen and C. Roering, Some aspects of the geology, structure and metamorphism of the Southern marginal zone of the Limpopo metamorphic complex, Special Publication of the Geological Society of South Africa 8 (1983), pp. 121-142. 
England and Thompson, 1984 P.C. England and A.B. Thompson, Pressure-Temperaturetime paths of regional metamorphism. I. Heat transfer during the evolution of regions of thickened continental crust, Journal of Petrology 25 (1984), pp. 894-928.

Frei et al., 1999 R. Frei, T.G. Blenkinsop and R. Schonberg, Geochronological and late Archean Razi and Chilimanzi suite of granites in Zimbabwe: implications for the late Archean tectonics of the Limpopo belt and Zimbabwe Craton, South African Journal of Geology 102 (1999), pp. 55-63.

Fripp, 1983 R.E.P. Fripp, The Precambrian geology of the area around the Sand River near Messina, Central Zone, Limpopo mobile belt. In: W.J. Van Biljon and J.H. Legg, Editors, The Limpopo belt Special Publication 8, Geological Society of South Africa, Johannesburg (1983), pp. 89-102.

Harley, 1989 S.L. Harley, The origin of granulites: a metamorphic perspective, Geological Magazine 126 (1989), pp. 215-247.

Harris and Holland, 1984 N.B.W. Harris and T.J.B. Holland, The significance of cordierite-hypersthene assemblages from the Beit bridge region of the Central Impopo Belt; evidence for rapid decompression in the Archean?, American Mineralogist 69 (1984), pp. 1036-1049.

Hisada and Miyano, 1996 K. Hisada and T. Miyano, Petrology and microthermometry of aluminous rocks in the Botswanan Limpopo Central Zone: evidence for isothermal decompression and isobaric cooling, Journal of Metamorphic Geology 14 (1996), pp. 183-197.

Hisada et al., 2005 K. Hisada, L.L. Perchuk, T.V. Gerya, D.D. Van Reenen and B.K. Paya, $P-T$-fluid evolution in the Mahalapye Complex, Limpopo high-grade terrane, eastern Botswana, Journal of Metamorphic Geology 23 (2005), pp. 313-334.

Hofmann et al., 1998 A. Hofmann, A. Kroner and G. Brandl, Field relationships of midto late Archean high-grade gneisses of igneous and sedimentary parentage in the Sand River, Central Zone of the Limpopo belt, South Afirca, South African Journal of Geology 101 (1998), pp. 185-200.

Holland and Powell, 1998 T.J.B. Holland and R. Powell, An internally consistent thermodynamic data set of petrological interest, Journal of Metamorphic Geology 16 (1998), pp. 309-343.

Holzer et al., 1998 L. Holzer, R. Frei, J.M. Barton and J.D. Kramers, Unravelling the record of successive high grade events in the Central Zone of the Limpopo belt using $\mathrm{Pb}$ single phase dating of metamorphic minerals, Precambrian Research 87 (1998), pp. 87 115. 
Holzer et al., 1999 L. Holzer, J.M. Barton, B.K. Paya and J.D. Kramers, Tectonothermal history in the western part of the Limpopo belt: test of tectonic models and new perspectives, Journal of African Earth Sciences 28 (1999), pp. 383-402.

Horrocks, 1983 Horrocks, P.C., 1983. The Precambrian geology of an area between Messina and Tshipise, Limpopo mobile belt. In: Van Biljon, W.J., Legg, J.H. (Eds.), The Limpopo belt, Special Publication of the Geological Society of South Africa, vol. 8, pp. 81-88.

Jaeckel et al., 1997 P. Jaeckel, A. Kroner, S.L. Kamo, G. Brandle and J.I. Wendtk, Late Archaean to early Proterozoic granitoid magmatism and high-grade metamorphism in the central Limpopo belt, South Africa, Journal of the Geological Society of London 154 (1997), pp. 25-44.

Kamber and Biino, 1995 B.S. Kamber and G.G. Biino, The evolution of high-T low- $P$ granulites in the Northern Marginal Zone sensu stricto, Limpopo belt, Zimbabwe - the case for petrography, Schweizerische Mineralogische und Petgrographische Miteilungen 75 (1995), pp. 427-454.

Kamber et al., 1995a B.S. Kamber, T.G. Blenkinsop, I.M. Villa and P.S. Dahl, Proterozoic transpressive deformation in the Northern Marginal Zone, Limpopo belt, Zimbabwe, Journal of Geology 100 (1995), pp. 490-508.

Kamber et al., 1995b B.S. Kamber, J.D. Kramers, R. Napier, R.A. Cliff and H.R. Rollinson, The Triangle Shearzone, Zimbabwe, revisited, new data document an important event at $2.0 \mathrm{Ga}$ in the Limpopo belt, Precambrian Research 70 (1995), pp. $191-213$.

Klemd et al., 2003 R. Klemd, A. Schmidt, J. Martin and J.M. Barton, P-T path constraints from metapeletic rocks east of the Venetia kimberlite pipes, Central Zone, Limpopo belt, South Africa: have gthese rocks seen granulite-facies conditions?, South African Journal of Geology 106 (2003), pp. 129-148.

Kramers et al., 2001 J.D. Kramers, K. Kreissig and M.Q.W. Jones, Crustal heat production and style of metamorphism: a comparison between two Archean high grade provinces in the Limpopo belt, Southern Africa, Precambrian Research 112 (2001), pp. $149-163$.

Kreissig et al., 2000 K. Kreissig, T.F. Nagler, J.D. Kramers, D.D. Van Reenen and C.A. Smit, An isotopic and geochemical study of the northern Kaapvaal Craton and the Southern Marginal Zone of the Limpopo belt: are they juxtaposed terranes?, Lithos 50 (2000), pp. 1-25.

Kreissig et al., 2001 K. Kreissig, L. Holzer and R. Frei et al., Geochronology of the Hout River Shear Zone and the metamorphism of the Limpopo belt, Southern Africa, Precambrian Research 109 (2001), pp. 145-173. 
Kroner et al., 1998 A. Kroner, A.A. Nemchin, P. Jaeckel, A. Hofmann, G. Brandl and R.T. Pidgeon, Field relationships and age of supracrustal Beit Bridge Complex and associated granitoid gneisses in the Central Zone of the Limpopo belt, South Africa, South African Journal of Geology 101 (1998), pp. 201-213.

Kroner et al., 1999 A. Kroner, P. Jaeckel, G. Brandl, A.A. Nemchin and R.T. Pidgeon, Single zircon ages for granitoid gneisses in the Central Zone of the Limpopo belt, Southern Africa and geodynamic significance, Precambrian Research 93 (1999), pp. 299-337.

Light, 1982 M.P.R. Light, The Limpopo belt: a result of continental collision, Tectonics 1 (1982), pp. 325-342.

Luais and Hawkesworth, 1994 B. Luais and C.J. Hawkesworth, The generation of continental crust: an integrated study of crust-forming processes in the Archean of Zimbabwe, Journal of Petrology 35 (1994), pp. 43-93.

McCourt and Armstrong, 1998 S. McCourt and R. Armstrong, SHRIMP U-Pb zircon geochronology of granites from the Central Zone of the Limpopo belt, Southern Africa: implications for the age of the Limpopo Orongeny, South African Journal of Geology 101 (4) (1998), pp. 329-338.

McCourt and Vearncombe, 1987 S. McCourt and J.R. Vearncombe, Shear zones bounding the central zone of the Limpopo mobile belt, Southern Africa, Journal of Structural Geology 9 (1987), pp. 127-137.

McCourt and Vearncombe, 1992 S. McCourt and J.R. Vearncombe, Shear Zones of the Limpopo belt and adjacent granitoid-greenstone terranes, implications for late Archaean collision tectonics in Southern Africa, Precambrian Research 55 (1992), pp. 553-570.

Mkweli et al., 1995 S. Mkweli, B.S. Kamber and M. Berger, Westward continuation of the craton-Limpopo belt tectonic break in Zimbabwe and new age constraints on the timing of thrusting, Journal of the Geological Society of London 152 (1995), pp. 77-83.

Mouri et al., this volume Mouri, H., Brandl, G., Whitehouse, M., de Waal, S., Guiraud, M., this volume. CL-imaging and ion probe dating of single zircon grains from a highgrade rock from the Central Zone, Limpopo belt, South Africa: evidence for a single metamorphic event at $\sim 2.0 \mathrm{Ga}$. Journal of African Earth Sciences,

Perchuk et al., 1996 L.L. Perchuk, T.V. Gerya, D.D. Van Reenen, O.G. Safnov and C.A. Smit, The Limpopo metamorphic complex, South Africa. Part II: Decompression and cooling regimes of granulites and adjacent rocks of the Kaapvaal craton, Petrologiya 4 (1996), pp. 571-599. 
Perchuk et al., 2000 L.L. Perchuk, T.V. Gerya, D.D. van Reenan, A.V. Krotov, O.G. Safonov, C.A. Smit and M.Y. Shur, Comparative petrology and metamorphic evolution of the Limpopo (South Africa) and Lapland (Fennoscandia) high-grade terrains, Mineralogy and Petrology 69 (2000), pp. 69-107.

Perchuk et al., 2006 L.L. Perchuk, T.V. Gerya, D.D. van Reenan and C.A. Smit, $P-T$ paths and a problem of high-temperature polymetamorphism, Petrology 14 (2006), pp. $117-153$.

Retief et al., 1990 Retief, E.A., Compston, W., Armstrong, R.A., Williams, I.S., 1990. Characteristics and preliminary $\mathrm{U}-\mathrm{Pb}$ ages of zircons from Limpopo belt lithologies. Extended abstracts, Limpopo Workshop, Rand Afrikaans University, Johannesburg, pp. 95-99.

Ridley, 1992 J.R. Ridley, On the origin and tectonic significance of the charnockite suite of the Archean Zimbabwe, Precambrian Research 55 (1992), pp. 407-427.

Robertson and Du Toit, 1981 I.D.M. Robertson and M.C. Du Toit, Mobile Belts. In: D.R. Hunter, Editor, The Precambrian of the Southern Hemisphere, Elsevier, Amsterdam (1981), pp. 641-671.

Roering et al., 1992 C. Roering, D.D. Van Reenen and C.A. Smit et al., Tectonic model for the evolution of the Limpopo belt, Precambrian Research 55 (1992), pp. 539-552.

Rollinson, 1989 H.R. Rollinson, Garnet-orthopyroxene thermobarometry of granulites from the north marginal zone of the Limpopo belt, Zimbabwe. In: J.S. Daly, R.A. Cliff and B.W.D. Yardley, Editors, Evolution of Metamorphic Belts vol. 43, Geological Society Special Publication (1989), pp. 331-335.

Rollinson, 1993 H.R. Rollinson, A terrane interpretation of the Archaean Limpopo belt, Geological Magazine 130 (1993), pp. 755-765.

Rollinson and Blenkinsop, 1995 H.R. Rollinson and T. Blenkinsop, The magmatic, metamorphic and tectonic evolution of the North Marginal Zone of the Limpopo belt in Zimbabwe, Journal of the Geological Society of London 152 (1995), pp. 66-75.

Smit et al., 1992 C.A. Smit, C. Roering and D.D. Van Reenen, The structural framework of the Southern Margin of the Limpopo belt, South Africa, Precambrian Research 55 (1992), pp. 51-67.

Smit et al., 2001 C.A. Smit, D.D. Van Reenen, T.V. Gerya and L.L. Perchuk, $P-T$ conditions of decompression of the Limpopo high-grade terrane: record from shear zones, Journal of Metamorphic Geology 19 (2001), pp. 249-268. 
Stevens and Van Reenen, 1992a G. Stevens and D.D. Van Reenen, Constraints on the form of the $P-T$ loop in the Southern Marginal Zone of the Limpopo belt, South Africa, Precambrian Research 55 (1992), pp. 279-296.

Stevens and Van Reenen, 1992b G. Stevens and D.D. Van Reenen, Constraints on the origin of metapelitic granulites in the Southern Marginal Zone of the Limpopo belt, Precambrian Research 55 (1992), pp. 303-319.

Taylor et al., 1991 R.S. Taylor, J.D. Krammers, S. Moorbath, J.F. Wilson, J.L. Orpen and A. Martin, $\mathrm{Pb} / \mathrm{Pb}, \mathrm{Sm}-\mathrm{Nd}$ and $\mathrm{Rb}-\mathrm{Sr}$ geochronology in the Archean Craton of Zimbabwe, Chemical Geology 87 (1991), pp. 175-196.

Treloar et al., 1992 P.J. Treloar, M.P. Coward and N.B.W. Harris, Himalayan-Tibetan analogies for the evolution of the Zimbabwe Craton and Limpopo belt, Precambrian Research 55 (1992), pp. 571-587.

Tsunogae and Van Reenen, 2006 T. Tsunogae and D.D. Van Reenen, Corundum + quartz and $\mathrm{Mg}$-staurolite bearing granulite from the Limpopo belt, Southern Africa: implications for a $P-T$ path, Lithos 92 (2006), pp. 576-587.

Tsunogae and Yurimoto, 1995 T. Tsunogae and H. Yurimoto, Single zircon U-Pb geochronology of the Limpopo belt by secondary ion mass spectrometry, Geochemical Journal 29 (1995), pp. 197-205.

Tsunogae et al., 1992 T. Tsunogae, T. Miyano and Ridley, Metamorphic $P-T$ profiles from the Zimbabwe Craton to the Limpopo belt, Zimbabwe, Precambrian Research 55 (1992), pp. 303-319.

Van den Berg and Huizenga, 2001 R. Van den Berg and J.M. Huizenga, Fluids in granulites of the Southern Marginal Zone of the Limpopo belt, South Africa, Contributions to Mineralogy and Petrology 141 (2001), pp. 529-545.

Van Reenen, 1983 D.D. Van Reenen In: W.J. Van Biljon and J.H. Legg, Editors, Cordierite + garnet + hypersthene + biotite-bearing assemblages as a function of changing metamorphic conditions in the Southern Marginal Zone of the Limpopo metamorphic complex, South Africa vol. 8, Geological Society of South Africa Special Publication (1983), pp. 143-167.

Van Reenen, 1986 D.D. Van Reenen, Hydration of cordierite and hypersthene, a description of the retrograde isograd in the Limpopo belt, South Africa, American Mineralogist 71 (1986), pp. 900-915.

Van Reenen et al., 1988 D.D. Van Reenen, C. Roering, C.A. Smit, J.F. Van Schalkwyk and J.M. Barton, Evolution of the northern high-grade margin of the Kaapvaal Craton, South African Journal of Geology 96 (1988), pp. 549-560. 
Van Reenen et al., 1990 D.D. Van Reenen, C. Roering, C.A. Smit and J.M. Barton Jr., The granulite facies rocks of the Limpopo belt, South Africa. In: D. Vielzeuf and P. Vidal, Editors, Granulites and Crustal Evolution NATO-ASI Series C211, Luwer, Dordrecht (1990), pp. 257-289.

Van Reenen et al., 1992 D.D. Van Reenen, C. Roering, L.D. Ashwal and M.J. de Wit, Regional geological setting of the Limpopo belt, Precambrian Research 55 (1992), pp. $1-5$.

Van Reenen et al., 2004 D.D. Van Reenen, L.L. Perchuk and C.A. Smit et al., Structural and $P-T$ evolution of a major cross fold in the Central Zone of the Limpopo high-grade terrain, South Africa, Journal of Petrology 45 (2004), pp. 1413-1439.

Watkeys, 1979 M.K. Watkeys, Explanation of the geological map of the country west of Beit bridge, Rhodesian Geological Survey Short Report (1979), p. 45.

Watkeys et al., 1983 Watkeys, M.K., Light, M.P.R., Broderick, T.J., 1983. A retrospective view of the Central Zone of the Limpopo belt, Zimbabwe. In: Van Biljon, W.J., Legg, J.H. (Eds.), The Limpopo belt, Special Publication 8, Geological Society of South Africa, Johannesburg, pp. 65-80.

White et al., 2002 R.W. White, R. Powell and G.L. Clarke, The interpretation of reaction textures in Fe-rich metapelitic granulites of the Mugrave Block, central Australia: constraints from mineral equilibria calculations in the system $\mathrm{K}_{2} \mathrm{O}-\mathrm{FeO}-\mathrm{MgO}-\mathrm{Al}_{2} \mathrm{SiO}_{3}-$ $\mathrm{SiO}_{2}-\mathrm{H}_{2} \mathrm{O}-\mathrm{TiO}_{2}-\mathrm{Fe}_{2} \mathrm{O}_{3}$, Journal of Metamorphic Geology 20 (2002), pp. 41-55.

Yoshioka and Wortel, 1995 S. Yoshioka and M.J.R. Wortel, Three dimensional numerical modelling of detachment of subducted lithosphere, Journal of Geophysical Research 100 (1995), pp. 20223-20444.

Zeh et al., 2004 A. Zeh, R. Klemd, S. Buhlmann and J.M. Barton, Pro- and retrograde P$T$ evolution of granulites of the Beit Bridge Complex (Limpopo belt, South Afrcia); constraints from quantitative phase diagrams and geotectonic implications, Journal of Metamorphic Geology 22 (2004), pp. 79-95.

Zeh et al., 2005 A. Zeh, T.J.B. Holland and R. Klemd, Phase relationships in gruneritegarnet-bearing amphibolites in the system CFMASH, with applications to metamorphic rocks from the Central Zone of the Limpopo belt, South Africa, Journal of Metamorphic Geology 23 (2005), pp. 1-17. 